\title{
Investigation of Sports Educated University Student's Empathy Level
}

\author{
Oguzhan Altungul ${ }^{1}$, Eyup Nacar ${ }^{1}$ \\ ${ }^{1}$ Firat Universitesı, Turkey \\ Correspondence: Oguzhan Altungul, Firat Unıversitesı, Turkey.
}

Received: August 2, 2017

Accepted: August 22, 2017

Online Published: August 25, 2017

doi:10.11114/jets.v5i10.2622

URL: https://doi.org/10.11114/jets.v5i10.2622

\begin{abstract}
Empathy is one of the cases which is necessary for people to live together. Because the first rule of establishing good relations with the close environment, it requires to understand what they're feeling in their good or bad moments and it needs to act accordingly.

The aim of this study is to investigate the empathy level of university students in terms of different variables and to understand if there are significant differences between them.

The scope of this research, test group is 150 university students from Firat University Faculty of Sports Sciences in different departments in 2015-2016 academic years.

To determining empathic tendency level of Faculty of Sports Sciences students, a survey was applied which is consisting two parts. In the first part of the survey, there are five questions to the demographics of the Faculty of Sport Sciences students participating in the research. In the second part of the survey "Empathic Education Scale" "EES" by (Dökmen) 1988 was used. Obtained data were analyzed with SPSS 17.0 package program, significant level was accepted as 0.05 .

As a result; It was determined that the empathic tendencies of university students receiving sports education are high. However, the empathic tendencies of the research group also resulted in the absence of any effects of gender, age, department, parental education levels.
\end{abstract}

Keywords: sports, physical education, student, empathy

\section{Introduction}

Mankind has been desired to live together with other people from the day that they existed until this century. By revealing the effective communication phenomenon between people has enabled them to understand each other better. But it should be known that, the first rule in the communication between people is try to understand other people's current feelings and able to adjust their behavior according to their current mood. For to keep up to developing and changing world will be possible by training youth who can effectively use their thinking and ideas, can take quick and correct decisions and being good relations with other people. The most important level of development of society has resulted from a good education. There are many important goals, one of them is to train savvy individuals, has ability to communicate in society and sensitive. This is possible through the introduction of the concept of empathy to people. The concept of empathy which is, decisive in the relations between people and directing social life, has been defined by researchers in various ways (Dökmen, 1994).

As a concept, empathy means to be aware of the thoughts and feelings possible means of others and in an objective way and living in cubits as a representative of the feelings and thoughts of people (Solak, 2011). The concept of empathy generally defined as, competence to understand the feelings of another person and his/her role and as a psychological grip without being in this role (Barut, 2004).

Barrett Lennard (1993) stated that when establishing empathy with the individuals this process occurs in four stages. First stage: to recognize and understand the feelings of the individual, the second stage; communicate, third stage; individuals feel that they have been heard and understood and the fourth stage is the self-expression of the individual (Mete, 2005, Gercek, 2005). In short, empathy is defined as understanding his feelings and thoughts by putting himself against the person.

When Empathy called Rogers and Rogers' empathic understanding comes to mind, has become today recognition that consensus on the majority (Rogers, 1994). According to this, empathy called as understanding his feelings and thoughts 
by putting himself against the person, understand people's feelings and thoughts correctly, feel and transmit this process to him/her (Dökmen, 1994)

The harmony, defined as the ability of individuals to establish and maintain good relationships with themselves and with their environment, begins with birth and develops to the end of life. General harmony is examined in two groups as personal harmony which is considered as the whole of behaviors developed to adapt to the environment of the individual, social harmony which is defined as meeting prestige in the society and fulfilling the requirement of having status (Basaran, 1992). It is suggested that personal cohesion is closely related to social role and social success, and social cohesion is closely related to having social attitudes and standards (Bostan, 1993).

Empathy is a process which is starting from the family and ongoing in the educational life and the business environment of individuals. There is a constant exchange of emotional in family atmosphere, mother has the highest empathy feeling in the family because, mother is the person that understand her child when she look to her child's behavior. While some researchers say empathy is innate, some says it is a phenomenon that can be developed by training. This is shows that empathy is process which starts at first grade until the university years. Empathy is a case of whether acquired by birth or not, people in the sports community should be high empathic trend. Because the futures sports administrators, coaches and teachers, must maintain a constant work in teams. Empathy is an indispensable phenomenon for the success of the team or group, or even for more integrity (Barut, 2004).

\section{Method}

The scope of this research, test group is 150 university students from Firat University Faculty of Sports Sciences in different departments in 2015-2016 academic years. In the research 150 students' (51) from management department, (50) from physical education teaching department, (49) from training education department are participated by coincidence method.

In the research "Empathic Education Scale" "EES" by (Dokmen) 1988 was used (Dokmen, 1988). There is two parts in the survey, in the first part there is 5 demographics to the students and in the second part there is 20 questions to determine the empathic tendency. This is a Likert survey and each questions scored from 1 to 5 . While calculating the scores 3.6.7.8.11.12.13.15 ${ }^{\text {th }}$ questions will calculate reverse. Score can be taken from the survey are minimum 20 and maximum 100.Total score expresses emphatic tendency scores of subjects. High scores shows that the empathic tendency is high, low scores shows that empathic tendency is low. Obtained data were analyzed with SPSS 17.0 package program, significant level was accepted as 0.05 .

In order to determine the age of the study group, section, maternal education and paternal education and emphatic difference between the scores of the scale trend, one way analysis of variance (ANOVA) was used. The t-test was used to determine the difference between genders with the scores from the scale significant level was accepted as 0.05 .

\section{Findings}

Table1. Frequency and Percentage Distributions Related to the Research Group Personal Variables

\begin{tabular}{|c|c|c|c|}
\hline & Variables & $\mathbf{N}$ & $\%$ \\
\hline \multirow[t]{3}{*}{ Gender } & Female & 70 & 46,7 \\
\hline & Male & 80 & 53,3 \\
\hline & Total & 150 & 100,0 \\
\hline \multirow{4}{*}{ Age } & $18-22$ & 75 & 50,0 \\
\hline & $23-27$ & 59 & 39,3 \\
\hline & $28+$ & 16 & 10,7 \\
\hline & Total & 150 & 100,0 \\
\hline \multirow{4}{*}{ Department } & Sports Management & 51 & 34,0 \\
\hline & Physical Education and Sports Teaching & 50 & 33,3 \\
\hline & Trainer Education & 49 & 32,7 \\
\hline & Total & 150 & 100,0 \\
\hline \multirow{5}{*}{ Mother Education Status } & Not Literate & 39 & 26,0 \\
\hline & Primary Education & 30 & 20,0 \\
\hline & High School & 55 & 36,7 \\
\hline & University & 26 & 17,3 \\
\hline & Total & 150 & 100,0 \\
\hline \multirow{5}{*}{ Father Education Status } & Not Literate & 37 & 24,7 \\
\hline & Primary Education & 27 & 18,0 \\
\hline & High School & 59 & 39,3 \\
\hline & University & 27 & 18,0 \\
\hline & Total & 150 & 100,0 \\
\hline
\end{tabular}


When we look at table 1 we can see that, $70(\% 46,7)$ of the participants are female, $80(\% 53,3)$ of the participants are male. We can also see, 75 of the students $(\% 50,0)$ are aged $18-22,59$ of the students $(\% 39,3)$ are aged 23-27, 16 of the students (\% 10,7) are aged 28+. Otherwise, we can see that 150 student's (51) from management department, (52) from physical education teaching department, (49) from training education department. Besides we look the table 1 again we can see that $39(\% 26,0)$ of participated student's mothers are not literate, $30(\% 20,0)$ of primary education, $55(\% 36,7)$ of high school, $26(\% 17,3)$ of mothers has university grades. Father education levels are, $37(\% 24,7)$ of not literate, 27 $(\% 18,0)$ of primary school, $59(\% 39,3)$ of high school, $27(\% 18,0)$ of university grades.

Table 2. Empathic Tendency Descriptive Statistics of Research Group

\begin{tabular}{llll}
\hline $\mathbf{N}$ & Min & Max & Mean \\
\hline 150 & 40 & 92 & 69,33 \\
\hline
\end{tabular}

In the table 2 we can see the empathic tendency scale score means of Firat University Faculty of Sports Sciences Students as $(69,33)$ and it seems to be close to the overall highest scores obtained from the scale. This is shows that the participants from Firat University Faculty of Sports Sciences have higher empathic level.

Table 3. Relationship between Empathic Tendency Scale and Gender Variables of Research Group

\begin{tabular}{llllll}
\hline Variables & $\mathbf{N}$ & Mean & Sd & t & p \\
Female & 70 & 69,87 & 9,83 & 0,613 & 0,579 \\
Male & 80 & 68,86 & 10,25 & & \\
\hline
\end{tabular}

As we see in table 3 there is not a significant difference in the $t$ test results, which is made for to determine the difference between variables, of the students empathic tendency scale score means regarding the gender variables( $t=0,613 ; p>0,05)$.

Table 4. Relationship between Empathic Tendency Scale and Age Variables of Research Group

\begin{tabular}{llllll}
\hline Variables & N & Mean & Sd & F & p \\
\hline $18-22$ & 75 & 69,20 & 10,51 & 0,193 & 0,825 \\
$23-27$ & 59 & 69,83 & 7,79 & & \\
$28+$ & 16 & 68,12 & 10,03 & & \\
\hline
\end{tabular}

As we see in table 4 there is not a significant difference in one way analysis of variance (ANOVA) test results, which is made for to determine the difference between variables, of the students empathic tendency scale score means regarding the age variables $(\mathrm{p}>0,05)$.

Table 5. Relationship between Empathic Tendency Scale and Department Variables of Research Group

\begin{tabular}{|c|c|c|c|c|c|}
\hline Variables & $\mathbf{N}$ & Mean & Sd & $\mathbf{F}$ & $\mathbf{p}$ \\
\hline Sports Management & 51 & 67,92 & 11,25 & 0,801 & 0,451 \\
\hline $\begin{array}{l}\text { Physical Education and } \\
\text { Sports Teaching }\end{array}$ & 50 & 69,78 & 10,13 & & \\
\hline Training Education & 49 & 70,34 & 8,52 & & \\
\hline
\end{tabular}

As we see in table 5 there is not a significant difference in one way analysis of variance (ANOVA) test results, which is made for to determine the difference between variables, of the students empathic tendency scale score means regarding the department variables $(\mathrm{p}>0,05)$.

Table 6. Relationship between Empathic Tendency Scale and Mother Education Status Variables of Research Group

\begin{tabular}{llllll}
\hline Variables & N & Mean & Sd & F & p \\
\hline Not Literate & 39 & 69,02 & 9,09 & 2,325 & 0,077 \\
Primary Education & 30 & 69,43 & 9,49 & & \\
High School & 55 & 71,43 & 8,63 & & \\
University & 26 & 69,33 & 13,48 & &
\end{tabular}

As we see in table 6 there is not a significant difference in one way analysis of variance (ANOVA) test results, which is 
made for to determine the difference between variables, of the students empathic tendency scale score means regarding the mother education status variables $(p>0,05)$.

Table 7. Relationship between Empathic Tendency Scale and Father Education Status Variables of Research Group

\begin{tabular}{llllll}
\hline Değişkenler & N & Ort. & Sd & F & p \\
\hline Not Literate & 37 & 68,05 & 9,25 & 2,457 & 0,065 \\
Primary Education & 27 & 72,03 & 6,65 & & \\
High School & 59 & 70,59 & 10,43 & & \\
University & 27 & 65,62 & 12,01 & & \\
\hline
\end{tabular}

As we see in table 7 there is not a significant difference in one way analysis of variance (ANOVA) test results, which is made for to determine the difference between variables, of the students empathic tendency scale score means regarding the father education status variables $(\mathrm{p}>0,05)$.

\section{Discussion and Result}

Empathy is a phenomenon which lies in the presence of human. Although some researchers say that the empathy is a condition that can be obtained afterwards, they actually know that the situation that lies in people's life from the beginning, can be change in the future. Considering the results of this study also supported this idea.

We see that the research group has the lowest from the empathic tendency scale score as 40 , higher as 92 , and the means as 63,33 (table 2). This is shows that, the scores which is participants have from the empathic tendency scale is closer to the highest score that could be gotten from the scale and this means that the participants empathic tendency level is high. The empathic tendencies, was searched that varies according to gender; there was no significant difference between the study group and gender empathic tendencies. In Ekinci's empathic tendencies work, according to the gender of the teacher candidates were statistically significant difference in favor of women (Ekinci, 2009). This suggests the opposite in our study. However, there is a significant difference between the gender and empathic tendencies in studies which have made by Ercoskun and Kiraz and this is supports our study (Ercoskun, 2005, Kiraz, 2011).

It has been found that, there is no significant difference between the empathy scores and age variables (table 4). This is similar to Kiraz's study (Kiraz, 2011). In a study that investigation of teacher candidates empathy tendency regarding some variables, made by Onay, empathy tendency has been investigated regarding the age variables and in the analyze results there were no significant difference (Onay et al, 2015).

There is not a significant difference between empathic tendency and department variables. The study of Ermen's is supports our study (Ermen, 2007).

Research groups mother and father education status and empathic tendency scores has been matched and there is not a significant difference between variables. In the study that made by Ercoskun and Kiraz they reached the same results (Ercoskun, 2005, Kiraz, 2011).

As a result: it has been determined that sport educated university student's empathy level as high. But it is found that, a gender, age, mother and father education status and department variable not effects the empathy levels.

In the light of these findings, in educational activities this could be told to students that the empathy is important and how they can make it real, empathy education programs could be set up to develop their empathy ability.

It is considered that our study will be literature knowledge for the researchers who are studying on different branches to develop the empathic tendency of students.

\section{References}

Barut, Y. (2004). Conflict Trends in Secondary Level Teacher Empathic Tendency Levels of employees of the Agency for Investigation of some variables. XIII. National Congress of Educational Sciences, Malatya.

Başaran, F. (1992)."Psycho-Social Development, carried out a study on children age 7-11", 2nd edition. Ankara. Ankara University Press, 21.

Bostan, S. (1993). "Adolescents age 14-16 Investigation and Compliance Levels of Parental Attitude", not Issued M.Sc., Ankara University, Ankara.

Dökmen, Ü. (1988). "Empathy A New Model Based Measuring and Improving the Psychodrama”, Ankara University Faculty of Educational Sciences Journal, 21(1-2), 155-190. 
Dökmen, Ü. (1994). "Art and Daily Life Communication Conflict and Empathy", Istanbul. Publishing System, 119-132.

Ekinci, Ö. (2009). Investigation of Empathy and Critical Thinking Disposition of Teachers, Unpublished Master's Thesis, Cukurova University, Institute of Educational Sciences, Adana.

Ercoşkun, M. H. (2005). Investigation of Empathy Skills of Different Variables of Teacher Trainees, Master Thesis, Ataturk University, Institute of Social Sciences, Erzurum.

Ermen, G. (2007). Selcuk University in the School of Physical Education and Sports Sports Student Studying Empathic Tendency Comparison with the behavior of their leaders Preferred, Selcuk University, Institute of Health Sciences, Konya.

Kiraz, C. (2011). Narcissistic Personality Traits Empathic Tendency of the Faculty of Education Students, Master Thesis, Yeditepe University, Institute of Social Sciences, Istanbul.

Mete, S, \& Gerçek, E. (2005). Study of Empathic Tendency of Education and Skills Nursing Students Receiving the PBL methodC.Ü. Nursing Journal, 9(2), 12.

Onay, İ., Egüz, Ş., \& Ünal, A. (2015). Study of Empathic Tendency of Teacher Candidates According to Various Variables. The Journal of International Social Research, 8(40).

Rogers, C. R. (1994)."Art and Daily Life Communication Conflict and Empathy", Istanbul. Publishing System, 119-132.

Solak, N. (2011). Exercising and Investigation of relationship do with empathy Aggression Levels between the Levels of High School Students "Corum Example" Master Thesis, Gazi University, Institute of Educational Sciences, Ankara.

\section{Copyrights}

Copyright for this article is retained by the author(s), with first publication rights granted to the journal.

This is an open-access article distributed under the terms and conditions of the Creative Commons Attribution license which permits unrestricted use, distribution, and reproduction in any medium, provided the original work is properly cited. 